\title{
"Transductive Urbanism" A Method for the Analysis of the Relational Infrastructure of Malled Metropolitan Centres in Auckland, New Zealand
}

\author{
By Manfredo Manfredini* \\ Xin Tian \\ Ross Jenner \\ Asu Besgen
}

This article discusses the theoretical framework and methodology developed for research on comparative urbanism devoted to emerging phenomena in rapidly expanding cities. It focuses on problems related to the right to the city, particularly addressing questions of participation in the production of space. The exploration of progressive social and spatial fragmentation of urban environments concentrates on the peculiar changes occurring in the main nodes of Auckland, the largest polycentric urban area of New Zealand. Primary places of this urban transformation are the shopping malls of latest generation that dominate the newly formed metropolitan centres. The presented methodology aims to interpret the heterotopic spatial introversions of these centres and describe their specific forms of spatial transductions. Its specific analytical methods are designed to provide indications of the emerging transformation of the role of public space in the interpersonal sphere of sociability. This involves the exploration of the agency of new digital media as instruments for the emergence of independent and autonomous recombinant forms in the new urban condition. The methods are combined to analyse and compare conceptions and experiences of physical, social and eidetic spatialities. Their application is expected to provide empirical support to the theoretically hypothesised, strong correlation between the increasing dis-embedding strength of territorial infrastructure and the emergence of networked "representational" recombinations occurring with the latest 'malling' form.

\section{Introduction}

In contemporary cities, shopping malls increasingly define the structure and organisation of public spaces, expanding the role of the "world in miniature" found by Walter Benjamin ${ }^{1}$ in the arcades of 19th century Paris. The new commercial spaces, set free from the tight intertwining of central-city

\footnotetext{
* Lead Author, The University of Auckland, New Zealand.

${ }^{\dagger}$ The University of Auckland, New Zealand.

\$ The University of Auckland, New Zealand.

Karadeniz Technical University, Trabzon, Turkey.

1. Walter Benjamin, Paris, capital of the nineteenth century (Cambridge, MA: Harvard University Press, 1935/2004), 165.
} 
networks, have increasingly developed their autonomy and supremacy in the articulation of public-relational life. Their growth has generated a new urban element that assumes a pivotal role in the development of suburban areas and, in some cases, in the redevelopment of historical centres.

Recently, with the shift from the modern integrated shopping mall (A mall) to the post-civil scalable, more-than-consumerist mall (A+ mall), these centres have strongly developed their social, cultural and economic roles. ${ }^{2,3,4,5,6} \mathrm{~A}+$ malls have augmented their primacy as public places of relational activities, significantly expanding the already remarkable cultural, entertainment and lifestyle elements of A malls. ${ }^{7,8}$ Their operators have fully embraced the recently introduced experiential turn: ${ }^{9}$ a model change that improves visitor engagement with highly interactive, eventful and characteristic environments that seamlessly merge real, fictional and virtual realms, emphasising the cognitive and sensorial emotional dimensions.

The new form of malling has been pervasive in the development of Australasian cities. Its diffusion distinctively characterises the important growth of major New Zealand cities, particularly affecting Auckland - the largest city, home to approximately 1.5 million people. Some structural aspects of the Auckland context have facilitated this development: a yearly population growth rate persistently above $1 \%$, a noticeable work-life balance, ${ }^{10,11}$ a widespread use of new mobile-digital communication technology ${ }^{12}$ and, importantly, the presence of very innovative protagonists of malling industry - particularly the Westfield-Scentre Group - one of the world leaders in the sector. $^{13,14}$

2. Peter H. Bloch, Nancy M. Ridgway, and Scott A. Dawson, "The shopping mall as consumer habitat," Journal of retailing 70, no. 1 (1994): 23-42.

3. Margaret Crawford, "The world in a shopping mall," in Variations on a theme park: The new American city and the end of public space (ed.) M. Sorkin (New York, NY: Hill and Wong, 1992), 3-30.

4. Jeffrey S. P. Hopkins, "West Edmonton mall: Landscape of myths and elsewhereness," Canadian Geographer 34 (1990): 2-17.

5. Jon Goss, "The 'magic of the mall': An analysis of form, function, and meaning in the contemporary retail built environment," Annals of the Association of American Geographers 83, no. 1 (1993), 18-47.

6. John Urry, The tourist gaze: Leisure and travel in contemporary societies (London, England: Sage, 1990).

7. Tomas Pernecky and Tazim Jamal, "(Hermeneutic) phenomenology in tourism studies," Annals of Tourism Research 37, no. 4 (2010): 1055-1075.

8. Greg Richards and Robert Palmer, Eventful cities: Cultural management and urban revitalisation (Oxford, England: Butterworth-Heinemann, 2010).

9. Manfredo Manfredini and Ross Jenner, "The virtual public thing: De-re-territorialisations of public space through shopping in Auckland's urban space," Interstices: Journal of Architecture and Related Arts 16 (2015): 75-81.

10. New Zealand Immigration, Balanced lifestyle, 2010, retrieved from https://www.new zealandnow.govt.nz/why-choose-nz/balanced-lifestyle.

11. "The world's most "liveable" cities," The Economist (2015, August 18), retrieved from www.economist.com.

12. Nielsen, New Zealand Multi-screen Report (2015).

13. Colliers International, Retail adept at adapting, New Zealand Retail 2014, Highlights, (2014), retrieved from http://www.colliers.co.nz. 
Consequently, of the nine Auckland metropolitan centres ${ }^{15}$ that are either anchored by one large shopping mall, or composed of little more than that ${ }^{16}$, three have A+ malls. These malls, with their attractiveness, size, amenities and patronage (the largest one exceeding 12 million per year) have subsumed the entire functions of their metropolitan centre (two of them, Sylvia Park and Botany Town Centre with its associated large format retail cluster, are even recognised as exclusive metropolitan centres by the current zoning regulation). Their relation with their context is of a dis-embedment that has exacerbated the criticalities of the previous models. Physically, they create a strong morphological and typological mismatch with their context. Socially, they polarise social infrastructure inside territories at the core of urban centres where interaction is limited.

\section{Methodological Framework: Theoretical Approach}

\section{Semi-public Space and the Right to the City}

The conceptual framework of this research grounds the methodological constructs of the empirical research, critically engaging with the change in form of spatial production occurring in the current profound socio-economic and geographic reset of our cities. The research further develops Henri Lefebvre's theoretical work on urban-space inhabitation, considering the city a product of historically specific material, conceptual and quotidian practices. ${ }^{17,18}$ Assuming the proposed ontogenetic capacity of space that - as David Harvey poses in "The Right to the City" - reflects the "freedom to make and remake ourselves and our cities", ${ }^{19}$ this study considers crucial the disempowerment of collectives in the processes of urbanisation that currently produce Auckland's urban centres. Internationally, this problem has been widely studied and related to limitations of public space in the fulfilment of social function concerning civic engagement, sense of ownership, inclusivity, accessibility and pluralism, ${ }^{20,21,22,23}$ and linked to the changes in everyday-life

14. Susan Fairgray, Auckland Retail Economic Evidence Base (2013), retrieved from www.aucklandcouncil.govt.nz.

15. Auckland Council, The Auckland plan (2012), retrieved from ttp://www.aucklandcou ncil.govt.nz.

16. Auckland Council, Proposed Auckland unitary plan (notified 30th September 2013, updated 8th July 2016), (2016), retrieved from http://unitaryplan.aucklandcouncil.govt.nz.

17. Henri Lefebvre, Le Droit à la ville (Paris, France: Anthropos, 1968).

18. Mark Purcell, "Possible worlds: Henri Lefebvre and the right to the city," Journal of Urban Affairs 36, no. 1 (2014): 141-154.

19. David Harvey, "The right to the city," New Left Review 53 (2008): 23.

20. Mike Davis, City of quartz: Excavating the future in Los Angeles (London, England: Verso, 2006).

21. Anna Minton, Ground control: Fear and happiness in the twenty-first-century city (London, England: Penguin, 2012).

22. Chantal Mouffe, "Deliberative democracy or agonistic pluralism?" Social Research 66 (1999): 745-758. 
patterns introduced by places of consumption. ${ }^{24,25,26,27}$

Relevant instances of the production of this kind of depoliticised space are the integrated mall enclosures. They are places that form the most imposing and rapidly developing examples of semi-public spaces. ${ }^{28,29,30}$ They epitomise what Lefebvre ${ }^{31}$ calls an impoverished condition of the "urban world reduced to its economic elements" since they are driven - as Harvey poses - by the relentless dynamics of capital accumulation that guarantee "the expansion of surplus production at a compound rate". ${ }^{32}$

\section{Typological Elusion and Heterotopic Spatial Introversions}

The architecture of A+ mall has significantly transformed the previous model of the twentieth century mall into a scalable complex of hybrid nature. Varying structures and compositions, aggregating semi-autonomous buildings with multifarious typology, deny any specific typological classification. However, they share an invariant characteristic: a heterotopic ${ }^{33,34}$ topological structure implemented with introverted scalable segmentation. ${ }^{35,36}$ Its spatial attributes are closely explored and comparatively evaluated in this research to disentangle the articulated environmental oppositions that produce their

23. Chantal Mouffe, "Public spaces and democratic politics," in Highrise-common ground. Art and the Amsterdam Zuidas Area (ed.) J. Boomgaard (Amsterdam, The Netherlands: Valiz, 2008), 135-156,

24. Ali Madanipour, Whose public space?: International case studies in urban design and development (London, England: Routledge, 2010).

25. Malcolm Miles and Steven Miles, Consuming cities (New York, NY: Palgrave Macmillan, 2004).

26. Richard Sennett, The conscience of the eye: The design and social life of cities (New York, NY: Norton, 1992).

27. Sharon Zukin, Naked city: The death and life of authentic urban places (New York, NY: Oxford University Press, 2009).

28. Francesco Chiodelli and Stefano Moroni, "Do malls contribute to the privatisation of public space and the erosion of the public sphere? Reconsidering the role of shopping centres," City, Culture and Society 6, no. 1 (2015): 35-42.

29. Michiel Dehaene and Lieven De Cauter, "Heterotopia in a postcivil society," in Heterotopia and the city: Public space in a postcivil society (ed.) M. Dehaene \& L. De Cauter (New York, NY: Routledge. 2008), 3-9.

30. Li Lin, "Indoor city and quasi-public space: A study of the shopping mall system in Hong Kong," China Perspectives 39 (2002): 46-52.

31. Henri Lefebvre, The urban revolution (Minneapolis: University of Minnesota Press, 1970/2003).

32. Harvey, The right to the city.

33. Michiel Dehaene and Lieven De Cauter, "The space of play: Towards a general theory of heterotopia," in Heterotopia and the city (ed.) M. Dehaene \& L. De Cauter (2008), 87-102.

34. Michel Foucault, "Of other spaces," in Heterotopia and the city (ed.) M. Dehaene \& L. De Cauter (2008), 13-29.

35. Manfredini and Jenner, "The virtual public thing".

36. Manfredo Manfredini, Ross Jenner and Paul Litterick, "Situated and community projects: New technologies: Auckland's public space of spectacle and consumption," paper presented at the 8th International Conference and Exhibition of the Association of Architecture Schools of Australasia (Christchurch, New Zealand, 2015). 
peculiar cognitive transfers - here defined as territorial transductions. ${ }^{37,38,39,40}$ Particular focus is given to the complex relations between external and internal conditions, configurational, social and semantic. On the one hand, the outer open spaces have labyrinthine paths and reduced walkability, often being areas either shared with or invaded by vehicles (typically carparks and traffic lanes). Their paths are structured on directional movements with straight axial lines and harsh boundaries (usually they have impervious thresholds, such as highly opaque walls and no-crossing kerb lines). On the other, the inner spaces have highly legible, hyper-connected, anchored and permeable movement networks. Their paths have highly transparent borders (some mall regulations require no less than $90 \%$ store-front transparency) that guarantee the uninterrupted deep visual apprehension of space and its activity. These paths are structured on intersecting loops with different characters that form the multiple precincts of homogeneous territorial sequences strong identity.

Territorial sequences, such as fashion retail precincts, are composed of seamlessly connected territorial units, such as women's or children's garment clusters, and sub-units, such as individual stores. Each territorial level is often themed and uses more or less explicit references that range from popular culture to historical heritage, from allegorical narrative to fantastic topoi. With their abundant symbolic and indexical system of references and iconic effects, each of these sequences and units has a very consistent internal storyline that is aimed to generate high memorability and recognition. Their consistency, however, is limited to each discrete segment, since there is little or no relation between neighbouring ones. The resulting contrast between such a juxtaposition of unrelated patches of suggestive narratives and the seamless continuity of their spatial accessibility produces a realm where shifts of contexts are multiple and continuous. The sudden territorial transductions emphasise and bring to the scale of the person the fragmentation characterising the wider pattern of the contemporary city.

Compensating for the cognitive fragmentation, these centres develop relevant forces of re-territorialisation and re-embedment for their high capacity of combining several factors that reverse the condition of their external urban spaces: enhanced connectivity of interior spaces, outstanding programmatic articulation and high levels of comfort and activation. ${ }^{41,42,43}$

37. Gilles Deleuze and Felix Guattari, Anti-Oedipus: Capitalism and schizophrenia (Minneapolis: University of Minnesota Press, 1997).

38. Rob Kitchin and Martin Dodge, Code/space: Software and everyday life (Cambridge, MA: MIT Press, 2011).

39. Rob Kitchin and Sung-Yueh Perng, Code and the city (London, England: Routledge, 2016).

40. Gabriel Popescu, "Deterritorialization and reterritorialization," in Encyclopedia of geography (ed.) B. Warf (Thousand Oaks, CA: Sage, 2010), 722-724.

41. Chiodelli and Moroni, "Do malls contribute to the privatisation of public space and the erosion of the public sphere? Reconsidering the role of shopping centres".

42. Joel Stillerman and Rodrigo Salcedo, "Transposing the urban to the mall: Routes, relationships, and resistance in two Santiago, Chile, shopping centers," Journal of Contemporary Ethnography 41, no. 3 (2012): 1-27. 
Spatially, these centres are conceived as systems with optimised movement networks, fine-grained configuration and strategic articulation in semiautonomous precincts. Functionally, they are planned for comprehensiveness, with great profusion and inclusion of multifarious activities, carefully distributed in networks composed of commercial and non-commercial precincts. These networks form a profuse social infrastructure with multiple kinds of urban amenities, including public institutions, such as libraries, citizen advice bureaux, army recruitment offices and non-profit organisations, such as support-service centres for development, health and wellbeing. Comfort-wise, they are provided with high-performance systems for the control of climate, light, sound and smell landscapes. With the establishment of clear hierarchic orders, ambience symmetry and distinctive landmarks, their spatial legibility is designed for intuitive navigation. Activation is continuously provided by dedicated management departments to improve and make public life festive through social, cultural and wellness events. ${ }^{44,45}$ This includes the creation of an intense digital atmosphere supported by enhanced electronic infrastructure, devices and services. ${ }^{46}$

Cumulatively, these advancements enable the mutation of modern shopping malls in more-than-consumerist venues. Their recreational, social and civic dimensions and their overabundant comprehensiveness poses them in antagonism to the traditional town centres with their genuinely collective public realm. The concentration of social and commercial infrastructure and amenities in the interior corresponds to their rarefaction in the primary urban catchment of the centres. The consequent polarisation of public life, whilst commodifying a large spectrum of activities - recreation, relational life, culture, health and civic engagement- exacerbates the crisis of the urban commons, supplanting the traditional participative processes of the production of collective space.

These semi-civic consumption centres constitute the framework for a large part of everyday public experience of increasing parts of the urban population. They play a key role in the transformation of the interpersonal sphere of sociability that has a significant spatial impact on processes of social integration and identity formation. The changes of relational life in these centres is mainly caused by the shift of people's interaction from face-to-face to mediated forms, through the power of digital communication. There, where the digital pervasion is at its highest in the public realm, ${ }^{47,48,49}$ prime forms of

43. Paco Underhill, Call of the mall: The geography of shopping (New York, NY: Simon and Schuster, 2005).

44. Elizabeth Howard, "New shopping centres: Is leisure the answer?" International Journal of Retail \& Distribution Management 35, no. 8 (2007): 661-672.

45. Richards and Palmer, Eventful cities: Cultural management and urban revitalisation.

46. Charles Dennis, Andrew Newman, Richard Michon, J. Josko Brakus and Len Tiu Wright, "The mediating effects of perception and emotion: Digital signage in mall atmospherics," Journal of Retailing and Consumer Services 17 (2010): 205-215.

47. George Ritzer, "Prosumption: Evolution, revolution, or eternal return of the same?" Journal of Consumer Culture (November 2013): 1-22.

48. George Ritzer, Paul Dean and Nathan Jurgenson, "The coming of age of the prosumer," American Behavioral Scientist 56, no. 4 (2012): 379-398. 
embodiment of the digital sphere in public space afford effective new practices of interaction that spatialise the electronic experience. These embodiments confirm the fundamental role played by space in the digital age. They are the tangible presence of a public sphere that has seen its digital component subsume a large part of the traditional media. With the addition of new powerful media, such as social-networking services, they introduce a twofold novelty: on the one hand, they activate new ways of place-based interaction - chiefly enabled by geolocation functionalities; on the other, they provide new means for the engagement of individuals in participative collective processes of production of space (Figures 1 and 2).

Major agencies interrupt the continuity and normality of the city, fragmenting urban patterns, community lives and cognitive experiences, and triggering powerful compensatory forces of socio-spatial relationality. These are ambivalent agencies of public-space fragmentation and integration that activate consubstantial forces of de-territorialisation and re-territorialisation. ${ }^{50,51,52}$ During recent decades, they have been globally pervasive, appearing in most of the various forms of the quasi-public realms and presenting the paradox of being places where enhancements in control and commodification of urban-life quality are accompanied by the emergence of sizeable independent and autonomous forces. The main trigger of this contradiction is the highly developed digital equipment that affords a privileged occurrence of embodiments of the digital sphere, allowing the collective power to elaborate complex and greatly connected layers of urban living.

\section{Methodology Structure and Articulation}

This proposed methodology is designed as a tool for the scrutiny of the peculiar ambivalence emerging in contemporary urbanism, concerning the parallel augmentation of both fragmentation and integration agencies occurring within the A+ malls. It aims to disentangle the multiple dimensions of these more-than-consumerist enclaves to validate the underlying, broader hypothesis that these places trigger recombinant agencies that are much stronger than the splintering forces they generate in supporting the development of social relationality.

New approaches to the study of the effects of increasingly suffused digital atmospheres in these depoliticised public spaces in our post-consumerist society have recently emerged. ${ }^{53,54,55,56}$ They focus on issues of collective

49. George Ritzer and Nathan Jurgenson, "Production, consumption, prosumption: The nature of capitalism in the age of the digital 'prosumer," Journal of Consumer Culture 10, no. 1 (2010): 13-36.

50. Deleuze and Guattari, Anti-Oedipus: Capitalism and schizophrenia.

51. Popescu, "Deterritorialization and reterritorialization."

52. Robert David Sack, Human territoriality: Its theory and history (Cambridge, England: Cambridge University Press, 1986).

53. Manfredini and Jenner. "The virtual public thing: De-re-territorialisations of public space through shopping in Auckland's urban space." 
participation in the production of urban space, considering the key emerging, empowering agency of multimodal communication. ${ }^{57,58,59}$

These are multidisciplinary approaches that have developed both theoretical and empirical studies, integrating analysis of physical and digital realms, to interpret and provide evidence concerning the contemporary transductionbased transformation of spatialised socio-relationality patterns.

Other studies informing our research explore the agencies of informally emerging interaction in everyday life ${ }^{60}$ of highly populated public places, from both deliberate actions and distracted activities, ${ }^{61,62}$ and strategic locations "right on or very close to the traffic lines" of malls' flows. ${ }^{63}$

Within this framework, our study offers a provisional sketch of what an empirically-based interpretive process of systematic spatial analysis might look like. It provides a multidimensional tool for the scrutiny of the changing social relationality. It is designed specifically to study the impact of integrated malls in Auckland and provide information for comparative international study, focusing on the differences between the A and A+ malls.

To verify the conflicting effects of these multidimensional spaces, we analyse and compare the primary elements of their fragmentation and the agencies for the restoration of unity in the urban experience. Focusing on the way spaces are in a constant state of becoming rather than being, ${ }^{64}$ this dyad elaborates upon Lefebvre's dialectic notion of abstract/differential space, focusing on the emerging production of difference ${ }^{65}$ and articulating two areas of empirical analysis that address, respectively, the conceived and experienced spaces. Abstract space refers to the key attributes of the abovementioned introverted topology and is interpreted as an agency of urban fragmentation, whose form, organisation and meaning are planned to generate realms of "plenitude," "bearing a heavy cargo of myth". ${ }^{66}$ Its investigation addresses three different aspects of the infrastructure, regarding physical, socio-spatial and representational configurations respectively. The study of the relations of these configurations in a cohesive environment enables us to

54. Manfredini, Jenner and Litterick. "Situated and community projects: New technologies: Auckland's public space of spectacle and consumption."

55. Ritzer, "Prosumption: Evolution, revolution, or eternal return of the same?"

56. George Ritzer, Paul Dean and Nathan Jurgenson, "The coming of age of the prosumer".

57. Richard Coyne, The Tuning of Place (Cambridge, MA: MIT Press, 2010).

58. Kitchin and Dodge, Code/space: Software and everyday life.

59. William Mitchell, Me++: The cyborg self and the networked city (Cambridge, MA: MIT Press, 2004).

60. John Chase, Margaret Crawford and John Kaliski, Everyday urbanism (New York, NY: The Monacelli Press, 1999).

61. George Baird, The space of appearance (Cambridge, MA: MIT Press, 1995).

62. George Baird, Public space: Cultural/political theory; Street photography: An interpretation (Amsterdam, Netherlands: SUN, 2011).

63. William Whyte, City: Rediscovering the center (Philadelphia: University of Pennsylvania Press, 2012), 9.

64. Bruno Latour, Reassembling the social: An introduction to actor-network-theory (London: Oxford University Press, 2005).

65. Henri Lefebvre, The production of space (Oxford, England: Blackwell, 1991).

66. Ibid, 28. 
untangle the complex constitutive role of the imposed spatial structure.

Differential space, by contrast, is interpreted as the realm of collective restorative agencies that, through pluralistic practices, undertake a unifying task aimed at recombining these illusionary, heterotopic spaces, dominated by corporations with communication-based forms of citizen re-appropriation. The investigation of differential space focuses on one specific aspect of the collective lived experience: perceived space. It evaluates its inception through the study of documentation produced by independent acts of spatial representation in the public sphere, using image-based communication shared on social media.

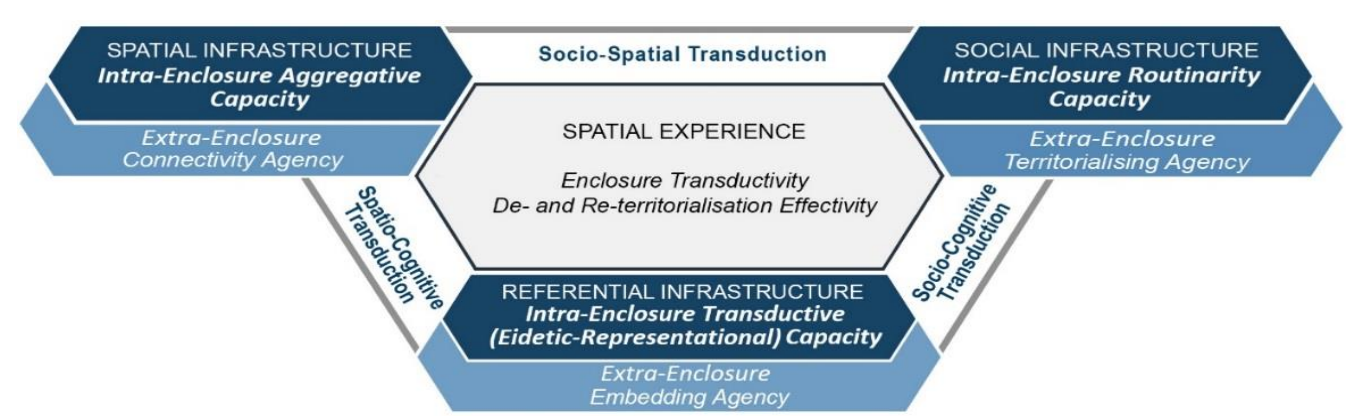

Figure 1. Diagram of the Research Method Articulation: Abstract Space Infrastructural Transductivity Capacity (External Set, in Blue) and Differential Space - Transductive Referentiality (Internal Element, in Light Grey)

Source: Manfredo Manfredini.

The conceptions of spaces are investigated in their infrastructural dimensions related to configuration, activities and representations. The experienced ones are explored through the attributes of their relational life. In establishing a relationship between these two spatialities, and particularly for the articulation of the first, the infrastructure of conceived space, we elaborate upon David Canter's ${ }^{67}$ seminal work, in which three essential areas are proposed to understand the nature of places as intersecting fields of analysis: space, activities and conceptions. With the adoption of this triad, along with critical consideration of John Montgomery's proposed elaboration ${ }^{68}$ in its refinement of the spatial elements (form, activity and image) that support people's attachment to place, the organisation of the structure of the analytical works assumes a threefold articulation as represented in Figure 1.

The configuration of space is explored to evaluate each mall in relation to the others and its urban context. It aims to identify and describe the physical, social and eidetic patterns, equipment and effectivity of both physical and digital infrastructure. The physical component explores the aggregative and connectivity agency of the configuration of malls (intra-enclosure capacity)

67. David Canter, The psychology of place (London, England: Architectural Press, 1977).

68. John Montgomery, "Making a city: Urbanity, vitality and urban design," Journal of Urban Design 3, no. 1 (1998): 93-116. 
versus the one in their urban precincts (extra-enclosure agency), evaluating differences between the support offered for the gathering of people by their internal and external environments. The social component investigates the territorialising agency of the social infrastructure of malls versus the one in their urban precincts, evaluating differences between the support offered to everyday routines and practices by their internal and external networks of urban amenity. The eidetic component investigates the referential agency of the urban image of malls versus the one in their urban precincts, evaluating the difference in the support offered to cognitive contextualisation by internal (spatially transductive) and external (spatially embedding) eidetic production. This component focuses on strength and consistency of spatial representations, exploring the representational infrastructure of each mall, to identify and describe physically and digitally conveyed semantic and sensorial referentiality.

Restoration agencies are investigated as emerging forms of differential space through constitutive attributes (formants) of communication, based on spatial representation. Differential spaces are those that reveal ambiguity and difference, capture trends of reconstituting integrity in the social body, and register contradictions and conflicts. They oppose difference (see the discussion on induced and produced difference in Lefebvre) ${ }^{69}$ generated internally to systems, expressed in various architectural types or spatial narratives and characters produced by iteration or selective contextualisation (e.g., implying semantic paradigms aiming to underpin sense of place with "authentic" or themed references). They promote ruptures with the existing formal and semantic determinations, emerging through the relational practices both in physical and digital dimensions. They are lived, representational spaces with autonomous and collective systems of spatial description that use images digitally conveyed through public social media as their main communication means. Representational space is explored to evaluate the agency of relational spatial referentiality of each mall in relation to its context and the city. It aims to identify and describe perceived and represented spatialities associated with both verbal and non-verbal symbols and signs.

The key constitutive attributes (formants) of the infrastructure of abstract space, used here to analyse comparatively the A and A+ malls in their urban context, consider physical and digital dimensions (and the amalgamation of these). They are articulated on three areas: configuration of space, sociospatial structure, and spatial representation. Our analysis uses only primary sources, and develops innovative methods to process digital data obtained from image-based social media (spatial perception) that substitute those traditionally provided by derivative or solicited responses. It employs a mixed method of quantitative and qualitative analysis, with simple indicators used to produce information that generalises the key character of the studied objects ${ }^{70}$

69. Lefebvre, The production of space, 372 et passim.

70. Tsutomu Yamada, Index indicator, index display method and recording medium storing index indicator program (Google Patents, 2000). 
and composite indicators, to summarise complex or multidimensional issues, reducing the size of the indicator list. ${ }^{71}$ The collection of data uses statistics, graphical and geographical data and information provided by local authorities and mall operators, and integrates and validates them with literature and sitesurvey observation and photographic documentation.

\section{Data Analysis}

\section{Background Data}

The analysis of the physical infrastructure supporting the aggregative capacity of malls begins with the collection and processing of background and basic data concerning the spatial attributes of each mall development and its urban precinct. The mall part includes four areas of both the shopping and entertainment zone, and the overall mall development consisting of: (1) general information: functional articulation, size, gross leasable area, ownership and management, designers, development timeline, accessibility (pedestrian and public and private transport), role in local development, development strategies and future plans; (2) building typology: building type (and subtypes), building articulation, spatial layout (geometry, orientation, attributes and type of accesses, number of storeys); (3) retail and recreation structure: sub-precincts, anchor-aisle articulation, type and connectivity of included open and service spaces (squares, lanes, green areas, car parks); and (4) building morphology: form, spatial assemblages, building and public-space patterns.

Regarding the urban precinct of malls, background information consists of: general information, areas of pedestrian catchment (5- and 10-minute pedestrian shed, considering effective paths calculated on existing walkable paths), publictransportation catchment (15- and 30-minute travel time by bus, urban light rail, subway calculated on existing street network with GIS applications), and privatetransportation catchment (15- and 30-minute driving time by car and scooter). Areas of catchment are also assessed using a gravity model that grants the establishing of probabilities of consumers at each origin location patronising each mall. The analysis uses the Huff model with three attractiveness variables for each mall: size (total leasable area), number of activities and number of carparks. For the calculation of distances, the analysis uses both the traditional (Euclidean with point-to point lines) and approximated travel time (along the street network) methods. Areas are then adjusted to match the limits of the smallest geographic units reported by Statistics New Zealand and allow the elaboration of the most recent Census datasets (2001, 2006 and 2013).

The identification of catchment areas (Figure 2), to be used in various parts of the analysis, is integrated with the determination of specific attributes concerning: accessibility, population data (number, density, age and ethnicity

71. Michaela Saisana and Stefano Tarantola, State-of-the-art report on current methodologies and practices for composite indicator development (Ispra, Italy: European Commission, 2002). 
distribution, and income, including variation during the last three censuses), role in urban/regional development (including milestone timelines) and digital interaction (Figures 3 and 4).

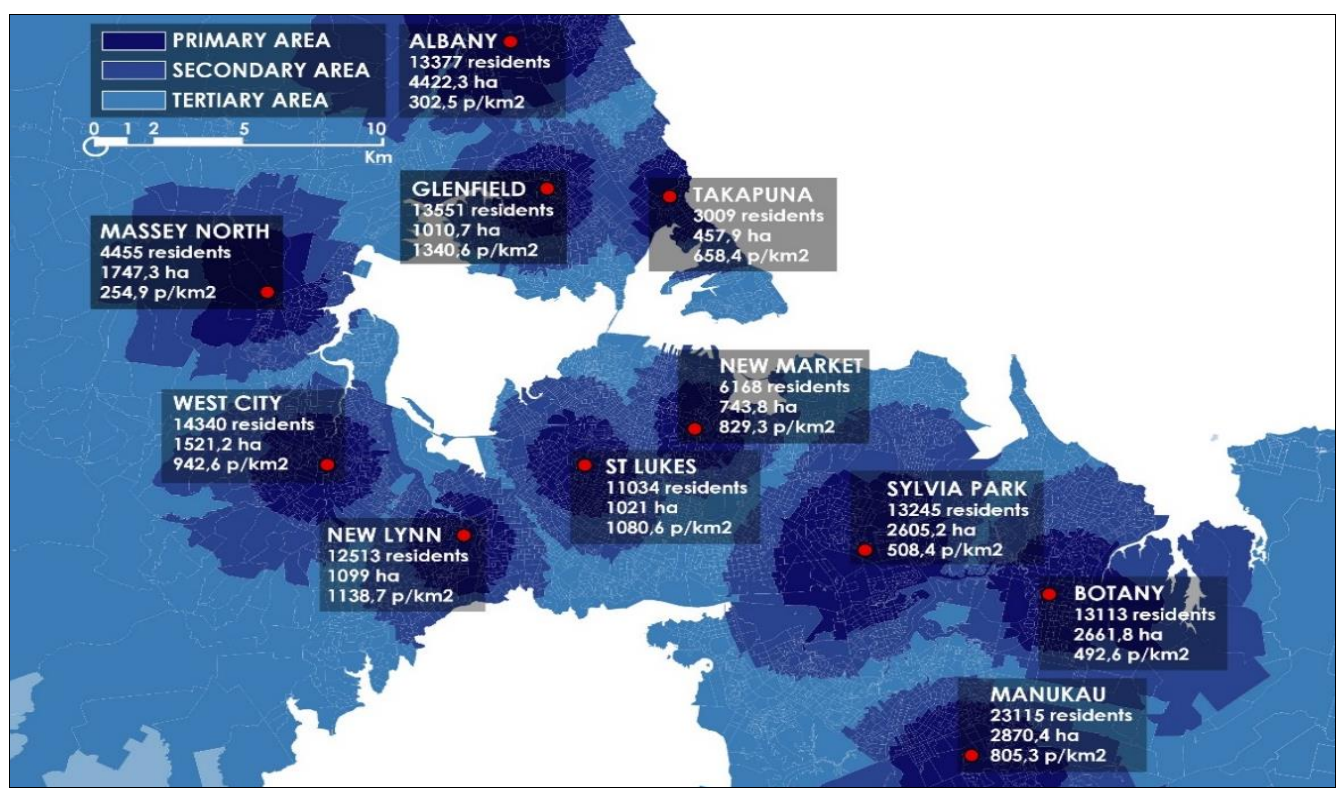

Figure 2. Map of the Primary Catchment Area (in Dark Grey) of the Nine Retail Regional Centres and Two Town Centres (Takapuna and North West) in the Auckland Conurbation with Usual Residents, Land Area and Population Density (2013 New Zealand Census data)

Source: Manfredo Manfredini and Jisoo Jung.

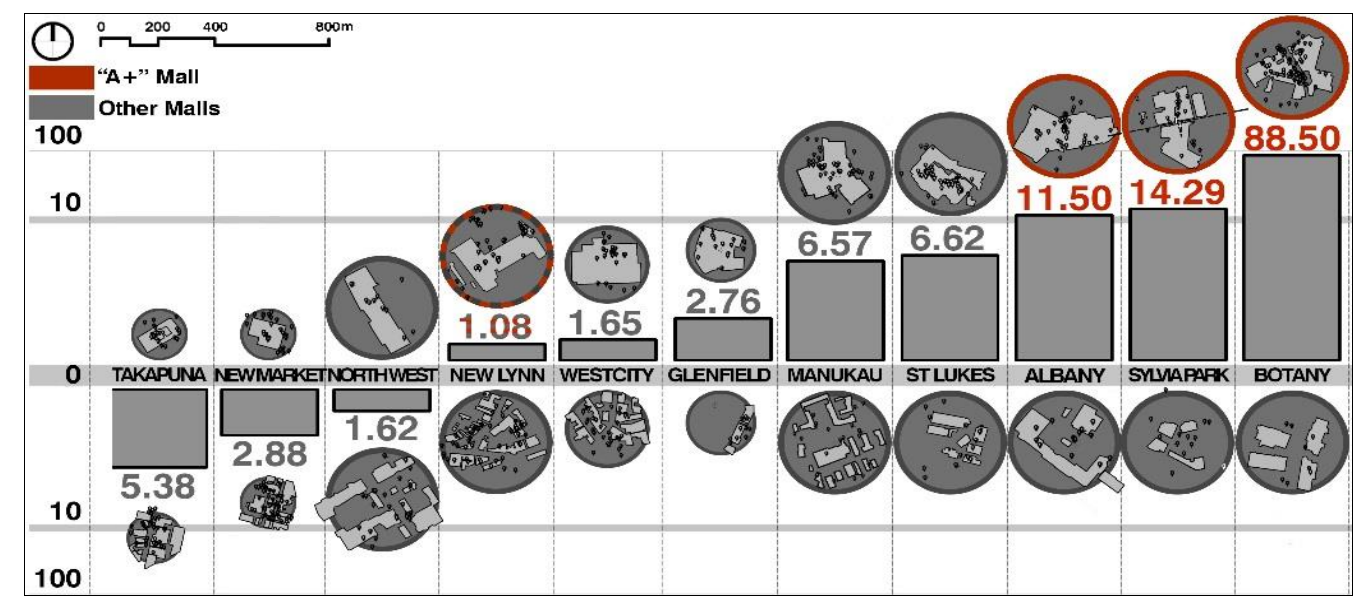

Figure 3. Chart Representing the Quantitative Relation between the Number of Visual Items Posted in Malls (Top) and Main Civic Areas (Bottom) of 11 Metropolitan Centres on the Photo- and Video-Sharing Social-Networking Service Instagram during the First Semester 2016

Source: Manfredo Manfredini and Anh-Dung Ta. 


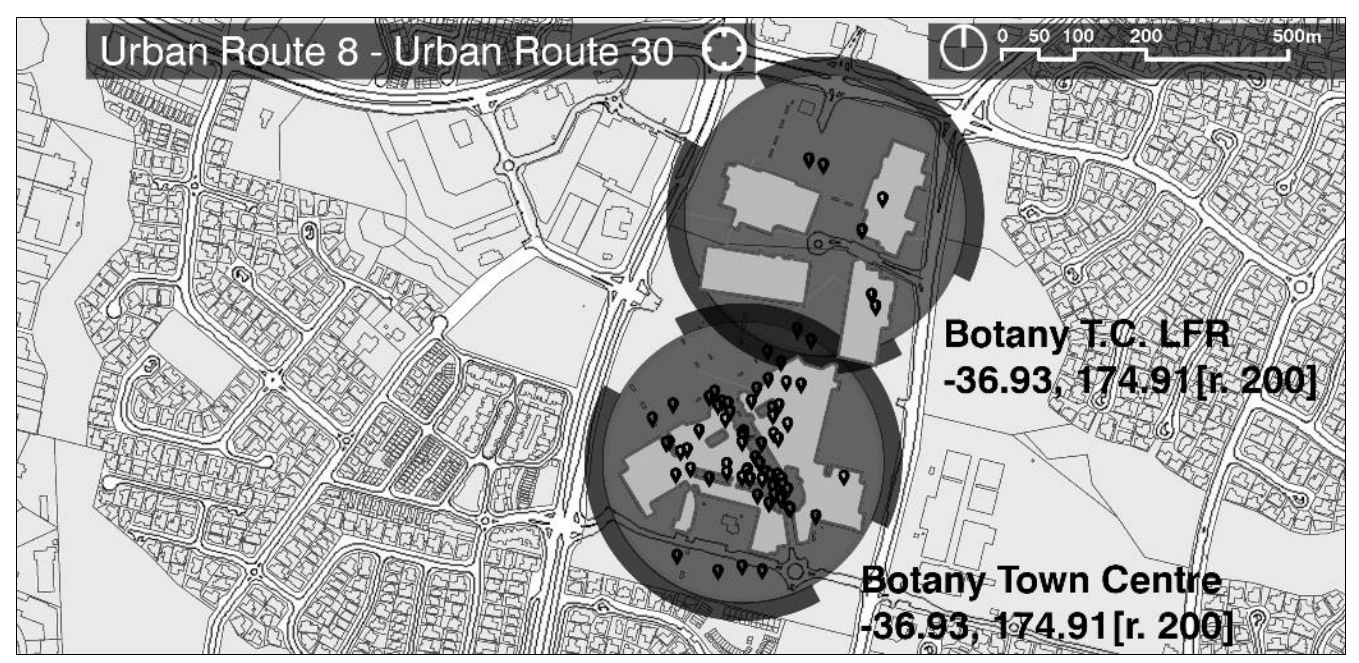

Figure 4. Map of Botany Town Centre with the Number of Visual Items in the Mall (Bottom) and Main Retail Areas (Top) on the Photo- and Video-Sharing Social-Networking Service Instagram during the First Semester 2016 Source: Manfredo Manfredini and Anh-Dung Ta.

\section{Configurational Structuration: Aggregative Capacity of Spatial Infrastructure}

Data collected in malls and related urban precincts are processed using conventional spatial-analysis variables and methods to assess spatial configurations. The analysis of infrastructural, structural, morphological and typological aspects, includes both physical and digital components ${ }^{72}$ and uses GIS applications and various dedicated software. It develops specific indicators that measure the relation between space and the social, environmental, infrastructural and cultural context.

The information resulting from the systematic investigation of spatial aspects of malls and related built environments (each with appropriate catchment areas) is elaborated and evaluated using three composite indicators, each evaluated on three dimensions: assessing spatial structuration, spatial effectivity and digital effectivity, as summarised in Table 1.

The dimensions for the evaluation of configurational structuration are: firstly, walkability - assessing pedestrian connectivity of the movement network in the mall urban precinct through variables regarding node density and inward and outward pedestrian accessibility to and from the mall and other parcels/buildings; secondly, granularity mix - assessing the discontinuities in urban morphology, considering spatial-grain attributes at the level of both malls and related built environments (spatial patterns and building typology); and, thirdly, territorial introversion - assessing the linkages between mall's precinct and the related urban context, particularly addressing the connectivity of relevant internalised "civic" outdoor areas.

The dimensions for the evaluation of configurational effectivity are:

72. Manfredo Manfredini and Aaron Hills, "Auckland public space and the evolution of the integrated enclosures of spectacle and consumption," in Intersections (ed.) L. Bravo (Bologna, Italy: City Space Architecture, in press). 
firstly, capillarity and hierarchical polarisation - assessing spatial relations between courtyards, halls, main concourses, aisles and corridors; secondly, usability - assessing the disposition of non-leasable indoor and outdoor space for activities as potentially active, semi-active, inactive surfaces; and, thirdly, permeability and pellucidity - assessing physical and visual permeability of frontages internal to malls and in related urban precincts.

The dimensions for the evaluation of the digital configuration effectivity are: accessibility - assessing wireless fidelity accessibility (quality of internet access: speed, coverage, time/data availability limits), device-interface articulation assessing the pervasion of digital interfaces (digital kiosks, navigator screen system, other digital devices), and digital-platform articulation - assessing the number of social-media platforms and channels, and dedicated mobile phone applications.

Table 1. Spatial Infrastructure Aggregative-Capacity Indicators

\begin{tabular}{|c|c|c|c|}
\hline $\begin{array}{l}\text { Assessment } \\
\text { Area }\end{array}$ & $\begin{array}{l}\text { Specific } \\
\text { Indicator }\end{array}$ & $\begin{array}{l}\text { Composite } \\
\text { Indicator I }\end{array}$ & $\begin{array}{l}\text { Composite } \\
\text { Indicator II }\end{array}$ \\
\hline \multirow{6}{*}{$\begin{array}{l}\text { Physical } \\
\text { Aggregative } \\
\text { Infrastructure }\end{array}$} & $\begin{array}{l}\text { Walkability (urban } \\
\text { precincts only) }\end{array}$ & \multirow{3}{*}{$\begin{array}{l}\text { Configurational } \\
\text { Structuration }\end{array}$} & \multirow{9}{*}{$\begin{array}{l}\text { Physical } \\
\text { Infrastructure: } \\
\text { Configurational } \\
\text { Embedment (spatial } \\
\text { topologic } \\
\text { introversion) of } \\
\text { malls in their } \\
\text { related urban } \\
\text { precincts }\end{array}$} \\
\hline & Granularity Mix & & \\
\hline & Territorial Introversion & & \\
\hline & Capillarity and & \multirow{3}{*}{$\begin{array}{l}\text { Configurational } \\
\text { Effectivity }\end{array}$} & \\
\hline & $\begin{array}{l}\text { Polarisation (malls only) } \\
\text { Usability }\end{array}$ & & \\
\hline & $\begin{array}{l}\text { Permeability and } \\
\text { Pellucidity (visual } \\
\text { permeability) }\end{array}$ & & \\
\hline \multirow{3}{*}{$\begin{array}{l}\text { Digital } \\
\text { Aggregative } \\
\text { Infrastructure }\end{array}$} & Accessibility & \multirow{3}{*}{$\begin{array}{l}\text { Digital } \\
\text { Configuration } \\
\text { Effectivity }\end{array}$} & \\
\hline & Interface Articulation & & \\
\hline & Platform Articulation & & \\
\hline
\end{tabular}

\section{Social Infrastructure Routinarity Capacity: Socio-Spatial Networks}

This research considers the mall environment as a substratum or structuring structure of socio-spatial practices of those who navigate them routinely. ${ }^{73}$ Drawing upon the theoretical work of Henry Lefebvre on the production of space, ${ }^{74,75}$ the investigation of these structures examines the consolidated relational practices (routines) in their relation to spatial organisation (conceived space) and people's real-life experiences (lived space). Consistent with the other parts of the analysis, the examination of spatial

73. Pierre Bourdieu, "The genesis of the concepts of habitus and field," Sociocriticism 2, no. 2 (1985): 11-24.

74. Henri Lefebvre, The production of space.

75. Ceri Watkins, "Representations of space, spatial practices and spaces of representation: An application of Lefebvre's spatial triad," Culture and Organization 11, no. 3 (2005): 209-220. 
attributes of socio-relational life will focus on both individual nodes and their networks, considering both the physical and digital realms.

For the empirical work, in the light of critical studies on the significant role of malls in shaping public routine in productive, relational and recreational practices, ${ }^{76,77,78,79}$ this research found relevant references for the articulation of the empirical analysis in studies on consumer experiences by Youn-Kyung Kim and on public activities by Jan Gehl. Kim's work provides pertinent descriptions of motivation-driven shopping practices and identifies their specific dimensions related to service, economics, diversion, conviviality and social activity. ${ }^{80,81} \mathrm{Gehl}^{82,83}$ proposes a partition of physical activities in public space into two classes - necessary and optional - that are prerequisites for the most relevant one, the social. In his interpretation, necessary activities are practices of a functional nature that are not performed on the basis of actors' choices but dependent on specific mandates, such as running errands. Optional activities are largely composed of recreational practices that include "those pursuits that are participated in if there is a wish to do so," such as sitting and sunbathing. ${ }^{84}$

The distinction between these two classes illuminates the construction of the key sub-indicator of socio-recreational routinarity. (Routinarity is here intended as the quality of a place of support for routine sequences.) It informs the articulation of the spectrum of practices ranging from basic/necessary through to relational/optional in four classes of different intensity of relational potential that segment practices in relation to spaces of procurement and consumption of goods and services. Particularly relevant is also Gehl's ${ }^{85}$ recognition of social exchange activities as unpredictable and spontaneous, resulting from practices linked to the two other classes in communal processes, as it provides a reference to our elaboration of the socio-relationality gradient embedded in the indicator of routine behaviour.

Studies of fundamental factors supporting the consolidation of visitors'

76. Goss, "The "magic of the mall": An analysis of form, function, and meaning in the contemporary retail built environment."

77. Mica Nava, "Modernity's disavowal: Women, the city and the department store," in Modern times: Reflections on a century of English modernity (ed.) M. Nava and A. O'Shea (London, England: Routledge, 1996), 38-76.

78. Richard Sennett, The fall of public man (New York, NY: Random House, 1977).

79. Sharon Zukin and Jennifer Smith Maguire, "Consumers and consumption," Annual Review of Sociology 30 (2004): 173-197.

80. Youn-Kyung Kim, Jikyeong Kang and Minsung Kim, “The relationships among family and social interaction, loneliness, mall shopping motivation, and mall spending of older consumers," Psychology \& Marketing 22, no. 12 (2005): 995-1015.

81. Youn-Kyung Kim, Minsung Kim and Jikyeong Kang, "Teens' mall shopping motivations: Functions of loneliness and media usage," Family and Consumer Sciences Research Journal 32, no. 2 (2003): 140-167.

82. Jan Gehl, Life between buildings: Using public space (Washington DC: Island Press, 2011).

83. Jan Gehl, Cities for people (Washington, DC: Island Press, 2013).

84. Jan Gehl, Life between buildings: Using public space (Washington DC: Island Press, 2011), 9 .

85. Ibid. 
routines have linked the attractiveness of shopping malls and the extension of their catchment areas ${ }^{86}$ to their capacity to respond to visitors' preferences with appropriate spatial organisation, provision of amenities and a variety of amusing events. These have informed the setup of the empirical work on social infrastructure, where the relation between spatial organisation and social relationality is analysed through the identification of measures that capture the individual and cumulative potential of formally instituted place-based activities.

The analysis of the social infrastructural routinarity capacity of malls started with the collection of background information concerning data of visitation numbers (overall and, where possible, disaggregated by times and areas and gauged by traffic data and heat maps), market positioning (commercial- or entertainment-sector specialisation, targeted customer segment), and business diversity (goods/service commercial and non-commercial offer articulation and proportion).

The analysis evaluates the socio-spatial network structure and predisposition to everyday-life routines of local communities, estimating the support to everyday practices provided by urban amenities, both as individual units and networks. It addresses the physical as well as the digital environment of malls and related urban precincts, using the appropriate catchment area for each study part. Four composite indicators, each evaluated on two dimensions, assess the specific socio-spatial network-articulation, community-life disposition and spatial and digital socio-relational potentials, as summarised in Table 2.

The dimensions for the evaluation of socio-spatial network-articulation are: anchored looping and induced diversity. The former assessing the clustering of activities in relation to the spatial structure of malls and their urban precinct, focusing on the mall's enhancement of the dumb-bell model in the quality and structure of interlocking paths looping through homogeneous zones. The latter assessing the profusion (number of formally defined activities), diversity (type and category of amenities in each commercial, leisure, cultural, community and civic-life group) and redundancy (abundance of both retail and non-retail units).

The dimensions for the evaluation of community-life disposition are: territorial embeddedness and eventful civility. The former assessing malls in their social environment, assessing a population's territorial distribution (day and night), social, demographic and economic elements (variation of selected attributes over the last three censuses) as well as access to amenities (distance between each residence and the closest amenity). The latter assessing the proportion and relevance of civil amenities present in each mall; and eventfulness, analysing the number and popularity of major public events organised by the operators of each mall.

The dimensions for the evaluation of spatial socio-relational potential are: element and network propensity to social integration. They both gauge the relative proportion of graded activities for goods and service provision. The analysis combines the unit (stores and kiosks) and sub-precinct levels

86. International Council of Shopping Centres, Guide for improving tenant mix (2014), retrieved from http://www.icsc.org. 
(homogeneous zones for either specific target groups, such as children, or goods/services provision type, such as general wear apparel). The evaluation of the socio-relational potential of space is the most relevant and complex in the assessment of the overall infrastructural routinarity. The estimation considers all individual activities for shopping, entertainment and recreation, conviviality, wellness, culture, community and civic life. Activities are investigated both quantitatively, measuring surface (leased area) and counting numbers (with internal, external and mixed access), and qualitatively. Qualitative evaluation estimates socio-relational performance, assessing typical characteristics of user interaction: number of participants, frequency (rare, occasional, discontinuous, and continuous), duration (short, medium long), exposure (to operators, acquaintances and strangers) and facilitation (induced sharing with non-acquaintances). The qualitative evaluations result in a classification of units and sub-precincts in four classes (primary, secondary, tertiary and quaternary), considering the relational potential (low, medium/ low, medium/high and high) of the performed activity (necessary, optional, and relational). Primary units and clusters respond to necessary needs in sectors such as nutrition (e.g., supermarkets), apparel (e.g., basic garments), health (e.g., clinics), finance (e.g., banks), education (e.g., kindergartens), and culture (e.g., libraries). Their configurations and practices are functionally driven and support low social interaction. Secondary units and clusters respond to optional needs in sectors such as nutrition (e.g., delicatessens), clothing (e.g., branded fashion shops), physical wellness (e.g., salon services), tourism (e.g., travel agencies), nutrition (e.g. food and beverage takeaway stores), and culture (e.g., magazine stores). Their configurations and practices are semifunctionally driven and support low to medium social interaction. Tertiary units and clusters provide services for higher optional needs, such as recreation and popular culture (e.g., cinema theatres, playgrounds and gaming centres) and nutrition (e.g., food court stalls). Their configurations and practices, oriented to interaction and entertainment, support medium to high social interaction. Quaternary units and clusters provide services for convivial and higher interaction needs with consumerist-socialising premises including services for hospitality (e.g., pubs, character restaurants and lifestyle cappuccino bars) and entertainment (e.g., activated playgrounds). Their configurations and practices, framing character-rich ambience and/or distinctive lifestyle, support high social interaction.

The evaluation of digital socio-relational potential gauges the predisposed digital environment using profusion and interaction as indicators. The former assessing abundance (availability of official social-media platforms and channels), diversity (mobile application functionality), usability (apps for instore way-finding, collection of information and data analytics), performance (frequency and quality of official posts, number of followers and forwarded posts), and effectivity (users' interactivity, likeness score of key activities). The latter assessing augmented reality penetration in both commercial (online/off-line integration) and recreational (penetration of social interaction applications, such as Pokémon Go) spheres. 
Table 2. Social Infrastructure Routinarity Capacity Indicators

\begin{tabular}{|c|c|c|c|}
\hline $\begin{array}{l}\text { Assessment } \\
\text { Area }\end{array}$ & $\begin{array}{l}\text { Specific } \\
\text { Indicator }\end{array}$ & $\begin{array}{l}\text { Composite } \\
\text { Indicator I }\end{array}$ & $\begin{array}{l}\text { Composite } \\
\text { Indicator II }\end{array}$ \\
\hline \multirow{6}{*}{$\begin{array}{l}\text { Physical } \\
\text { Spatio-Social } \\
\text { Infrastructure }\end{array}$} & Anchored Looping & \multirow{2}{*}{$\begin{array}{l}\text { Socio-Spatial } \\
\text { Network- } \\
\text { Articulation }\end{array}$} & \multirow{8}{*}{$\begin{array}{l}\text { Infrastructural } \\
\text { Routinarity }\end{array}$} \\
\hline & Induced Diversity & & \\
\hline & Territorial Embeddedness & \multirow{2}{*}{$\begin{array}{l}\text { Community-Life } \\
\text { Disposition }\end{array}$} & \\
\hline & Eventful Civility & & \\
\hline & $\begin{array}{l}\text { Socio-Relationality of } \\
\text { Elements }\end{array}$ & \multirow{2}{*}{$\begin{array}{l}\text { Spatial Socio- } \\
\text { Relational Potential }\end{array}$} & \\
\hline & $\begin{array}{l}\text { Socio-Relationality of } \\
\text { Networks }\end{array}$ & & \\
\hline \multirow{2}{*}{$\begin{array}{l}\text { Digital } \\
\text { Spatio-Social } \\
\text { Infrastructure }\end{array}$} & $\begin{array}{l}\text { Digital-Atmosphere } \\
\text { Profusion }\end{array}$ & \multirow{2}{*}{$\begin{array}{l}\text { Digital Socio- } \\
\text { Relational Potential }\end{array}$} & \\
\hline & $\begin{array}{l}\text { Digital-Atmosphere } \\
\text { Tangible Interaction }\end{array}$ & & \\
\hline
\end{tabular}

\section{Referential Eidetic Transductivity Infrastructure Capacity: Analysis on Spatial Representations}

The investigation of the image of the centres focuses on the semantic and sensorial attributes of the public spaces of malls and their related contexts. It analyses and compares the eidetic production potential of salient single elements and environmental scenes that can vividly identify and powerfully structure mental images of the environment, and evoke abundant and detailed meaning. ${ }^{87,88}$ The eidetic effectivity of the centre articulates authenticity, narration, or theming to define a coherent and distinctive identity, producing a recognisable (memorable) character of place. That character can either strengthen a place's specific environmental and cultural characteristics, or provide a new framework for its articulation using allo- or auto-referentiality. ${ }^{89}$

Analysis of these formants evaluates their cultural and environmental context as well as their potential for sensory distraction in physical and digital environments, in order to evaluate the potential of spatial transductions of malls. Analysis of transductivity identifies levels of perceived spatial embedment of malls, elaborating upon Lefebvre's ${ }^{90}$ opposing notions of induced and produced difference, respectively referring to abstract and differential spaces. Elements of environmental psychology ${ }^{91,92}$ are used to explore the eidetic of

87. Ralph Norman Haber and Ruth Haber, "Eidetic imagery: I. Frequency," Perceptual and Motor Skills 19, no. 1 (1964): 131-138.

88. Julia Simner, "Why are there different types of synesthete?" Frontiers in Psychology 4 (2013), 558.

89. Gunila Jivén and Peter J. Larkham, "Sense of place, authenticity and character: A commentary," Journal of Urban Design 8, no. 1 (2003): 67-81.

90. Lefebvre, The production of space.

91. Mary Jo Bitner, "Servicescapes: The impact of physical surroundings on customers and employees," Journal of Marketing 58 (1992): 57-71.

92. Lou W. Turley and Ronald E. Milliman, "Atmospheric effects on shopping behavior. A review of the experimental evidence," Journal of Business Research 49 (2000): 193-211. 
places, interpreting the studies on the urban image initiated by Kevin Lynch, to assess the potential of spaces to be imagined and represented, particularly expressed through the notion of "visibility in a heightened sense", 93 referring to objects that are not only able to be seen, but are presented sharply and intensely to the senses

Transductions are forms of transfers of lived experiences, where individuals move across unrelated contexts by physical and/or virtual means. The shift between spatialities is produced by various combinations of formal, social, and semantic properties. It often uses sophisticated theming devices that grant access to spatial otherness through substitution, mirroring, reduplication, and grafting. Transductions grow in intensity in key urban places of consumption, responding to the current strength to produce highly experiential shopping conditions that boost place character to construct enticing, distinctive and glamorous spatial assemblages. More and more, they effectively articulate internally coherent metanarratives ${ }^{94,95}$ and contribute to their eventfulness. They are fundamental elements for strategies aimed at invigorating creative life, production, and consumption, linking "creatives elsewhere and at the same time offering local creativity a stage and meeting ground". 96 Their effects are amplified by the pervasion of digital devices and software that, through their technicity, produce amalgamated realities with multimodal mixed geographies that, with their multi-chronic and semi-ubiquitous access, transduce space and enable it to unfold in multifarious ways. ${ }^{97,98,99}$ The comparative evaluation of the differentials on transductive potential is made on two levels that consider malls and the mall/urban context relationship.

Data collection and analysis methods of transductive eideticity focus on three aspects of the semantic and sensory attributes of spatial perception, considering physical and mediated (web-based media) realms. The assessment explores both malls and the related context at the urban precinct (commercialretail), suburb/neighbourhood (pedestrian catchment), district (census-ward scale) and city, and regional levels (considering also view shafts/sight lines/ landmark attributes). The collection of data in the urban district uses representative areas.

The analysis uses two multidimensional indicators that address what is usually defined as the "character" of a place, considering the cultural and environmental context, and the sensory "distraction" potential, as summarised

93. Kevin Lynch, The image of the city (Cambridge, MA: MIT press, 1960), 9.

94. Manfredini and Jenner, "The virtual public thing: De-re-territorialisations of public space through shopping in Auckland's urban space."

95. Manfredo Manfredini, Gloria Yuen and Steven Wu, "Public space and consumption 'spatial assemblages': Exploring Macau's places of spectacular otherness," paper presented at the 7th International Conference on Planning and Design (Tainan, Taiwan, 2013).

96. Richards and Palmer, Eventful cities: Cultural management and urban revitalisation, 472.

97. Kitchin and Dodge, Code/space: Software and everyday life, X.

98. Rob Kitchin, Martin Dodge, "Code and the transduction of space," Annals of the Association of American Geographers 95, no. 1 (2005): 162-180.

99. Kitchin and Perng, Code and the city. 
in Table 3. The former assesses the saliency of indexical, symbolic, and iconic elements of spatial structure, form, materiality, tectonic, and decoration/ public art. The latter measures the saliency of visual elements (legibility, order/ cluttering, and spaciousness) and experiential condition (togetherness, biophilia), producing important ("distractive") emotional stimulation that is different inside and outside mall precincts. Saliency of single elements and environmental scenes is graded on a scale that registers their distinctiveness level.

Table 3. Eidetic Transductivity Infrastructure Capacity Indicators

\begin{tabular}{|c|c|c|c|}
\hline $\begin{array}{l}\text { Subject } \\
\text { Area } \\
\end{array}$ & $\begin{array}{l}\text { Specific } \\
\text { Indicators }\end{array}$ & $\begin{array}{l}\text { Composite } \\
\text { Indicator I } \\
\end{array}$ & $\begin{array}{l}\text { Composite } \\
\text { Indicator II }\end{array}$ \\
\hline \multirow{4}{*}{$\begin{array}{l}\text { Semantic } \\
\text { and Sensory } \\
\text { Building / } \\
\text { Context } \\
\text { Character }\end{array}$} & $\begin{array}{l}\text { Cultural and } \\
\text { Environmental } \\
\text { Contextualism }\end{array}$ & \multirow{2}{*}{$\begin{array}{l}\text { Transductive Eideticity } \\
\text { (Distinctiveness grading) }\end{array}$} & \multirow{4}{*}{$\begin{array}{l}\text { Eidetic } \\
\text { Infrastructure: } \\
\text { Transductive } \\
\text { Referentiality }\end{array}$} \\
\hline & $\begin{array}{l}\text { Sensory "Distraction" } \\
\text { Potential }\end{array}$ & & \\
\hline & $\begin{array}{l}\text { Mediated Cultural and } \\
\text { Environmental } \\
\text { Context Embedment }\end{array}$ & \multirow{2}{*}{$\begin{array}{l}\text { Mediated-Transductive } \\
\text { Eideticity } \\
\text { (Distinctiveness grading) }\end{array}$} & \\
\hline & $\begin{array}{l}\text { Mediated Sensory } \\
\text { Distraction Potential }\end{array}$ & & \\
\hline
\end{tabular}

\section{Preliminary Test of Methods and Findings}

To review, refine and evaluate the overall consistency of the methods, but also to assess their feasibility, a preliminary test of each of them was carried out on representative case studies of each category (two to four of each of the A and A+ malls). The analysis used simplified analytical processes based on direct observations and data elaboration with the support of dedicated software. Results showed relevant differences between malls of the two categories in all indicators.

\section{Configurational Structuration: Aggregative Capacity of Spatial Infrastructure}

Significant examples of the results are the ones obtained from the analysis of connectivity (configurational structuration) and social-media service platform articulation (digital configuration effectivity). The test of methods evaluating urban connectivity considered the walkable area of malls in two conventional catchment sizes: primary and extended, respectively a five- and ten-minute walk from the centre. ${ }^{100}$ The preliminary test did not use the effective catchment, but simple circular areas. These areas were analysed assessing overall permeability by considering the density of connections (street intersections) and hindrances (irregularity in block size and form). Results showed A+ malls'

100. Ministry for the Environment, Urban Design Toolkit - third edition (Wellington, New Zealand: Ministry for the Environment, 2009). 
catchments (Albany and Botany) having movement networks with lower permeability than the catchments of A malls (Henderson and Manukau). The assessment of intersection density (total number in identified land areas) and frequency (average distance considering total street length) excluded from relevant nodes those of streets with depth less than 2 , such as cul-de-sacs (Figure 5).

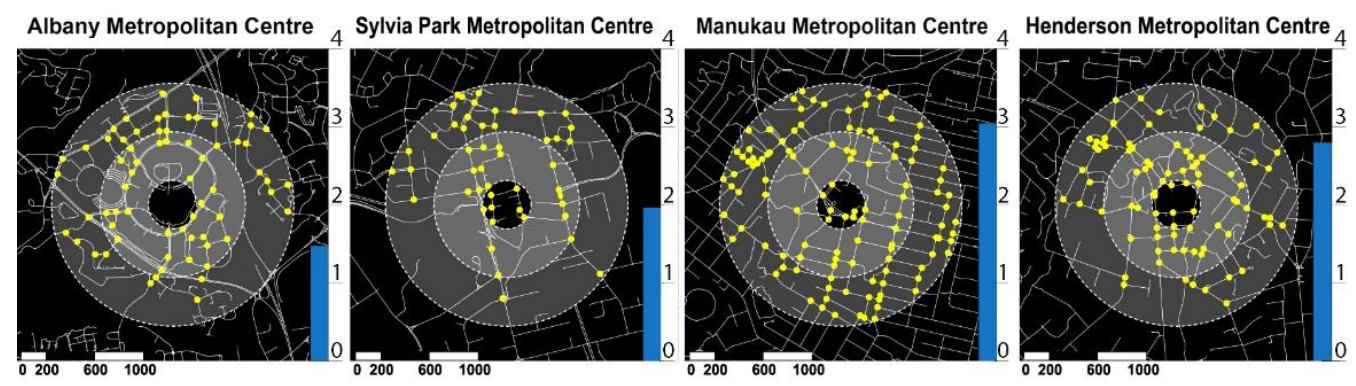

Figure 5. Connectivity Analysis. Maps and Graphs of Street Intersections, Location and Density in the (Simplified) Pedestrian Catchment Areas of Malls (Radius Increments of 400 Metres from the Core Mall Area)

Testing methods evaluating the articulation of social-media service platforms considered the number, functionality and activity of platforms activated by mall operators over a period of one month in 2015. Results, similar to those previously discussed by Manfredini and others ${ }^{101,102}$ showed $\mathrm{A}+$ malls having higher numbers and better performances than A malls in all three areas.

\section{Social Infrastructure Capacity for Routine: Analysis of Socio-Spatial Networks}

Significant examples of the results are the ones obtained from the analysis of anchored looping (articulation of socio-spatial networks), territorial embeddedness (community-life disposition), socio-relationality (spatial sociorelational potential), and digital-atmosphere tangible interaction (digital sociorelational potential).

Testing methods evaluating anchored looping explored the spatial and functional articulation of malls. The relation between distribution of activities and spatial structure was investigated and visualised with topological maps showing the main homogeneous paths, relevant entry points and main attractors (primary and secondary anchors). Results, showed A+ malls having higher numbers of loops, less overlapping paths, clearer identification of precincts with distinctive character and functions and more centrally located primary nodes than A malls (Figure 6).

101. Manfredini and Jenner, "The virtual public thing: De-re-territorialisations of public space through shopping in Auckland's urban space."

102. Manfredini, Jenner and Litterick, "Situated and community projects: New technologies: Auckland's public space of spectacle and consumption." 


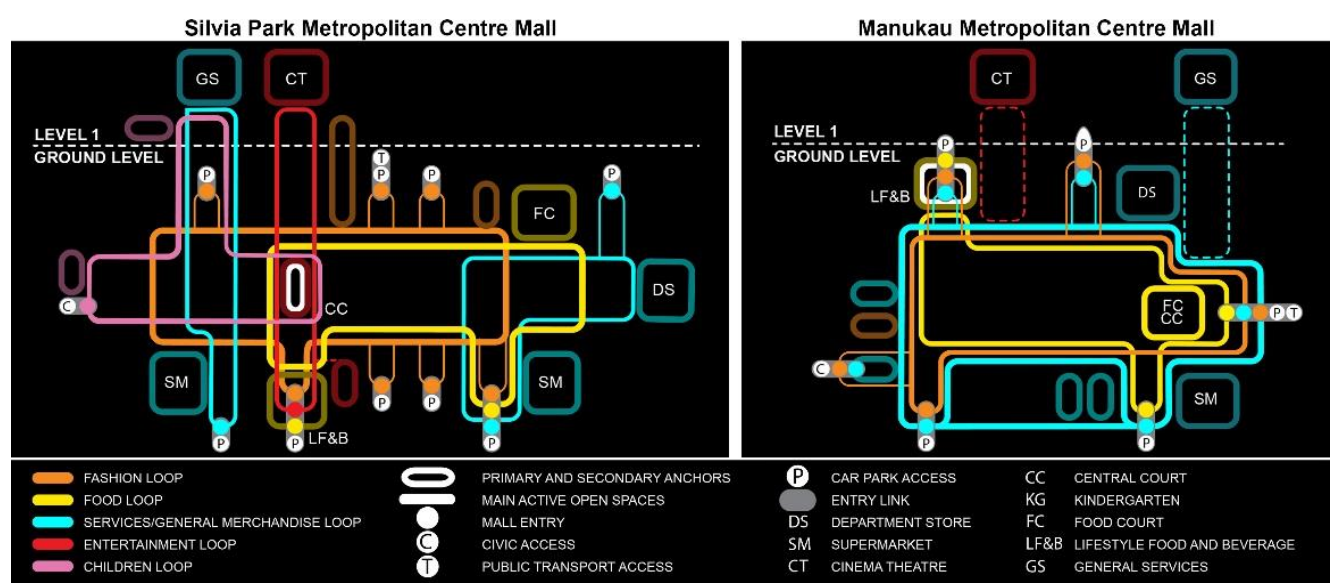

Figure 6. Anchored Looping Analysis. Topological Maps of Main Paths in Homogeneous Precincts

Source: Manfredo Manfredini, Angelo Bueno and Tanyalak Chalermtip.

Testing methods evaluating anchored territorial embeddedness explored the spatial and functional articulation of mall urban districts. The relation between distribution of urban amenities and spatial structure was investigated. Results of the analysis of Euclidean distances between each household residence and the closest urban amenity (excluding green areas) in the immediate driving catchment, as previously discussed by Manfredini and Hills, ${ }^{103}$ showed A+ malls having higher values than A malls (Figure 7).
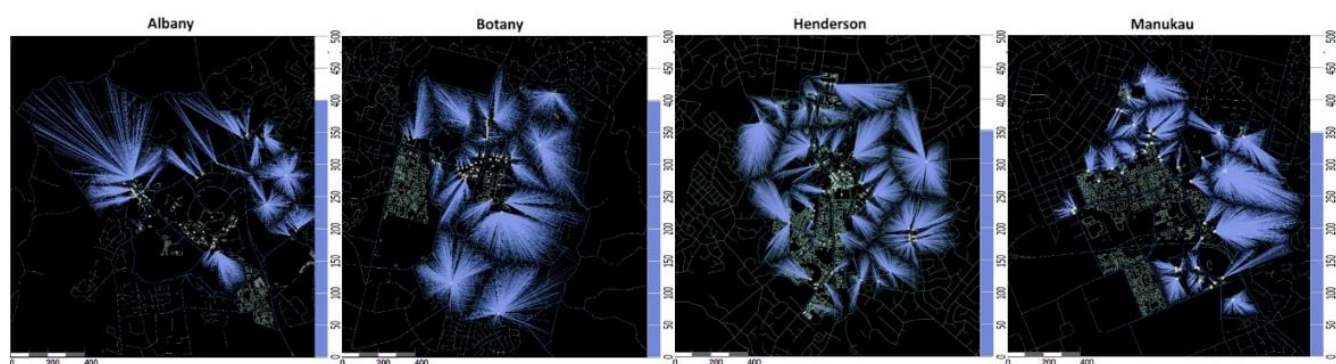

Figure 7. Urban Amenity Accessibility. Maps of the Euclidean Distance between Each Residence and the Closest Facility (Open Spaces Excluded). In the Five-Minute Driving Time Catchment Area of Malls Source: Manfredo Manfredini and Aaron Hills.

Testing methods to evaluate the potential of socio-relationality was based on conventional formal functional classification ${ }^{104,105,106,107}$ and was conducted

103. Manfredini and Hills, "Auckland public space and the evolution of the integrated enclosures of spectacle and consumption."

104. European Union, Glossary: Statistical classification of economic activities in the European Community (NACE) (2008), retrieved from http://ec.europa.eu/.

105. International Council of Shopping Centres, Canadian mall tenant classification (2009), retrieved from http://www.icsc.org/.

106. International Council of Shopping Centres, Guide for improving tenant mix.

107. The Urban Land Institute, Dollars and cents of shopping centers (Washington, DC: The Land Urban Land Institute, 2008). 
using direct site observation techniques and official mall data. Results, similar to those previously discussed by Manfredini and Jenner, ${ }^{108}$ showed A+ malls (Albany and Botany) having higher potential, mainly due to their larger proportion of quaternary units and clusters, both in number and surface, than A malls that have either minor (Manukau), or no (Henderson), lifestyle food and beverage clusters (Figure 8).

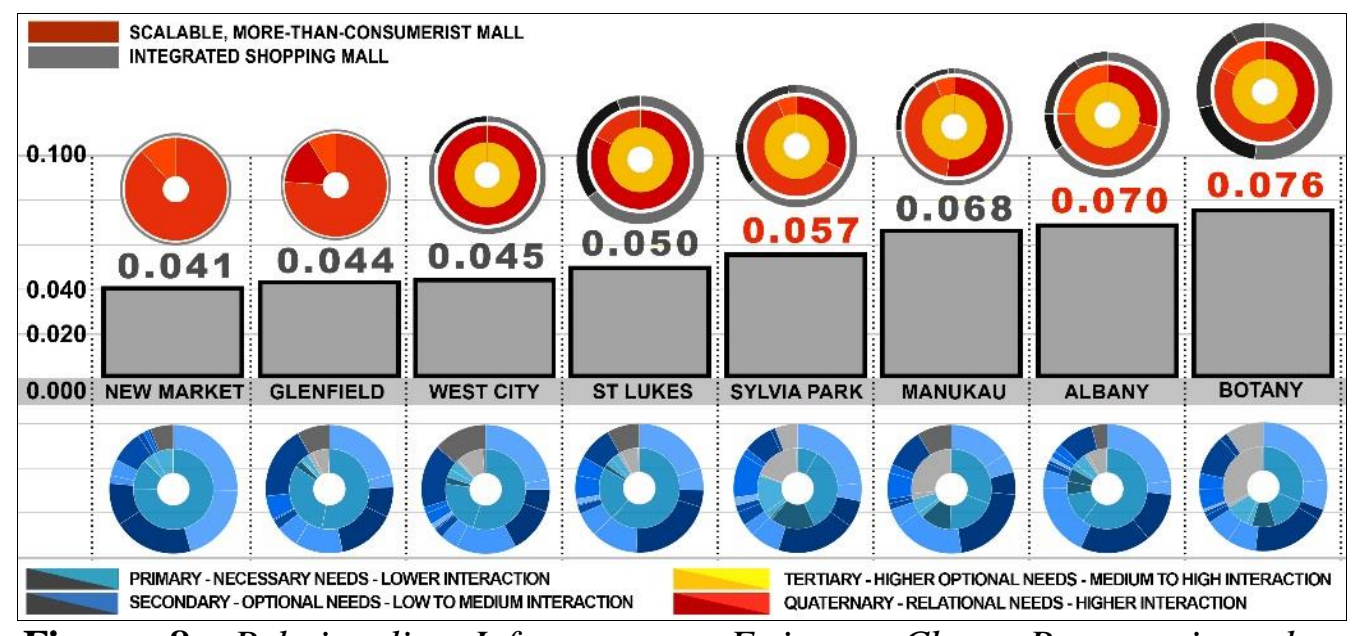

Figure 8. Relationality Infrastructure Estimate Chart Representing the Quantitative Relation (Surface) between the Amounts of Low to Medium/ Primary and Secondary Goods and Services Units (Bottom) and Medium to High /Tertiary (Cinema Theatre Clusters Excluded) and Quaternary Units (Top) of 8 Metropolitan Centres.

Source: Jisoo Jung.

Testing methods to evaluate the amalgamation of digital-atmosphere tangible interaction (digital socio-relational potential) comparatively assessed the space located in the mall areas and the space of the related urban precincts. The analysis used the most popular location-based augmented reality game, Pokémon Go, developed by Niantic and released in New Zealand in July 2016. The game has introduced new tactics of appropriation of public space with the formation of territories with strong sense of commonality between strangers. ${ }^{109}$ Results showed A+ malls (Albany and Botany) having higher playability capacity, due to their larger proportions of gaming nodes both for item collection, PokéStops, and team "battles," Pokémon gyms (Figure 9).

108. Manfredini and Jenner, "The virtual public thing."

109. Lee Humphreys, "Mobile social networks and urban public space," New Media \& Society 12, no. 5 (2010): 763-778. 

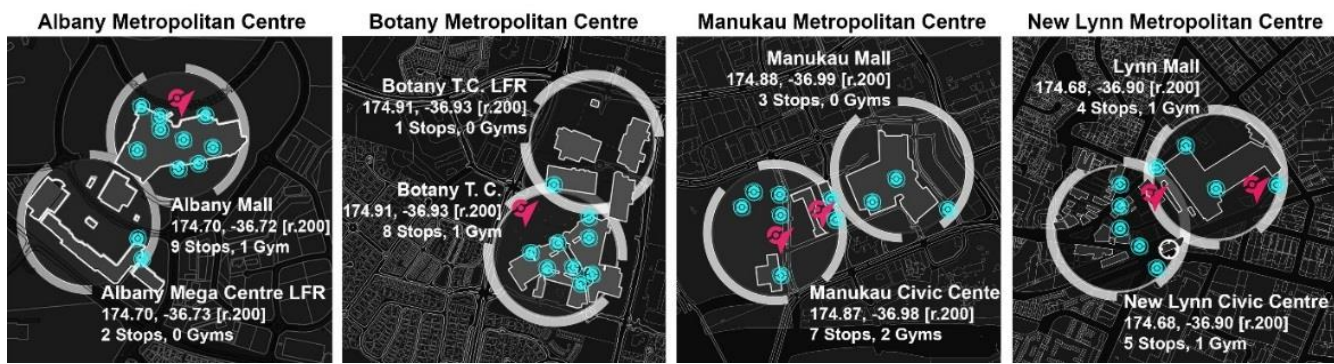

Figure 9. Playability Maps with Real-Life Locations of Niantic's Augmented Reality Game in Malls and Most Active Precincts of Related Metropolitan Centres in October 2016

Source: Manfredo Manfredini, Anita Chin and Linus Goh.

\section{Referential Eidetic Transductivity Infrastructure Capacity}

Significant examples of the results are the ones obtained from the legibility analysis of malls. Findings showed that the two mall categories have different levels of layout symmetry and polarisation patterns that ease people's wayfinding and strengthen their memorability: on one hand, A+ malls (Albany and Botany) have layouts with precise linear symmetry (both have patte d'oie structures), stronger spatial hierarchy (both have clear progressive centreperiphery transitions) and visual intelligibility (both have long and landmarkreinforced axial sightlines). These characteristics are confirmed by the analysis of visibility (Figure 10), where Space Syntax Depthmap X was used to test overall visibility and convex field extensions ${ }^{110}$ in relation to connectivity (axial analysis). Results showed higher values inside, or in proximity of, major internalised outdoor spaces (areas functionally designated as lifestyle precincts). These "convex spaces" are situated in core areas and directly connected to the major arterial aisles, all of them with visual access to the exterior of the mall (the accessibility from major aisles to main outdoor external spaces is always granted at their farthest end, either directly or through short and wide corridors).

On the other hand, A malls (Manukau and New Lynn) have partially symmetric layouts, less clear spatial hierarchy and visual intelligibility, hence offering problematical way-finding and memorability. Their visual analysis shows higher visibility values in internal spaces, which are either a major node positioned near the main entrance (Manukau) or distributed in various points of the main shopping concourse (New Lynn). Their main aisles are not always visually accessible by main external spaces. In another case (St Lukes), the visibility from the main aisle is totally contained within the indoor space.

110. Bill Hillier, Space is the machine: A configurational theory of architecture (London, England: Space Syntax, 2007). 

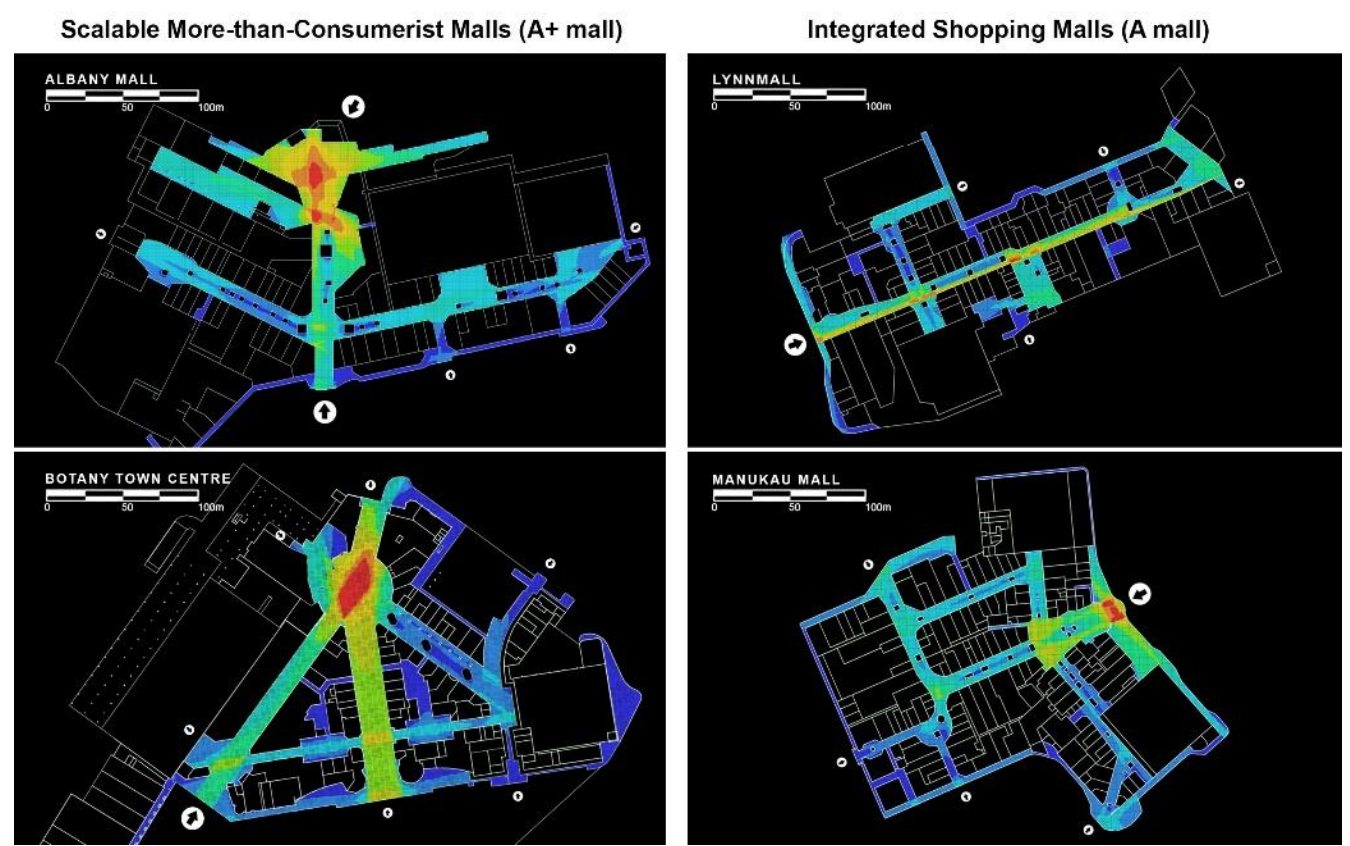

Figure 10. Visibility Graphs of the Intervisible Points Internal (Both Indoor and Outdoor) to Malls (DepthmapX)

Source: Manfredo Manfredini, Anita Chin and Linus Goh.

\section{Conclusions}

This paper discusses a comparative urbanism that, combining theoretical speculation and grounded-theory methodology, studies the important ongoing transformation of public-space practices in the metropolitan centre of Auckland. The centres scrutinised are dominated by imposing urban elements, the new commercial enclosures for shopping, entertainment and social life. They re-articulate the problems posed by traditional shopping malls to the development of a cohesive, inclusive and participatory society, presenting an enigmatic paradox. On one hand, their spaces offer realms with enhanced digital atmospheres that afford multiple digital embodiments (from simple on-line access to virtual reality) that have made them preeminent places of mediated communication. They reverse the isolation typical of the experience in traditional malls, eliciting high levels of people's activity in the public sphere. On the other hand, these public realms are framed in spatial systems with heterotopic introversion of a topologic kind that supports the progressive spatial and social fragmentation of the city. Their profusion of amenities and eventfulness polarises civic, commercial, recreational and convivial practices, reducing the liveliness of the neighbouring public spaces.

The study of these novel conditions requires a re-conceptualisation of traditional approaches that addresses the contemporary transduction-based socio-relationality patterns. The methodology discussed here reframes wellestablished theoretical and methodological frameworks, and, leveraging on it, combines consolidated and experimental methods. It develops an innovative 
application of the theoretical framework formulated by Lefebvre on the dialectic notion of abstract/differential space. Its analytical structure addresses spatial multidimensionality through the elaboration of a multilevel analysis that recognises the consubstantial nature of the conceived (three infrastructural dimensions) and perceived (one experienced dimension) spatialities of publicrelational life. It articulates them with specific sets of indicators on the corresponding opposing induced/produced difference.

Part of the methodology presented in this paper concerns conceived spatialities. It provides a specific tool to analyse comparatively, find correlations and describe the changing quality of public space in the metropolitan centres of Auckland. This method is, at this time, tentative and subject to revision, since not all difficulties faced while developing it were solved with preliminary and testing campaigns carried out in 2015 and 2016. These campaigns, however, allowed us to verify its feasibility and effectivity in managing a massive quantity of data and information. They also allowed verification that the limitations to collection and elaboration of validated data imposed by ethical principles and legal rights protecting physical and intellectual property do not compromise the effectiveness of results.

Ultimately, the elaboration of this methodology and its testing in selected instances not only confirms the hypothesis underpinning the initial theoretical convictions, but, most importantly, allows for an important revision of the interpretation of the theoretical framework throughout the analysis of data.

This part of the methodology constitutes the basis for the formulation of the other part that addresses the cumulative effects of pluralistic practices restorative of integrity in urban experience. When completed, it will help evaluate the emergence of a new articulation of the independent and autonomous recombinant agency of collective participation in the production of urban space in the most advanced spaces of our post-consumerist urban age. It will gauge the strength of correlations between the increasing agencies of dis-embedding "infrastructural" territorialisation and of networked "representational" re-combinations. Eventually, it will offer an instrumental contribution to the endeavour of understanding the ontogenetic forces of the complex and amalgamated spatialities of the post-civil, digital society.

\section{Bibliography}

Auckland Council. The Auckland plan. 2012. Retrieved from http://www.auckland council.govt.nz.

Auckland Council. Proposed Auckland unitary plan text. 2016. Retrieved from http://unitaryplan.aucklandcouncil.govt.nz.

Baird, G. The space of appearance. Cambridge, MA: MIT Press, 1995.

Baird, G. Public space: Cultural/political theory; Street photography: An interpretation. Amsterdam, Netherlands: SUN, 2011.

Benjamin, W. Paris, capital of the nineteenth century. Cambridge, MA: Harvard University Press, 1935/2004.

Bitner, M. J. "Servicescapes: The impact of physical surroundings on customers and 
employees." Journal of Marketing 58 (1992): 57-71.

Bloch, Peter H., Nancy M. Ridgway and Scott A. Dawson. "The shopping mall as consumer habitat." Journal of retailing 70, no. 1 (1994): 23-42.

Bourdieu, P. "The genesis of the concepts of habitus and field." Sociocriticism 2, no. 2 (1985): 11-24.

Canter, D. The psychology of place. London, England: Architectural Press, 1977.

Chase, J., M. Crawford and J. Kaliski. Everyday urbanism. New York, NY: The Monacelli Press, 1999.

Chiodelli, F. and S. Moroni. "Do malls contribute to the privatisation of public space and the erosion of the public sphere? Reconsidering the role of shopping centres." City, Culture and Society 6, no. 1 (2015): 35-42. doi:10.1016/j.ccs. 2014.12.002.

Colliers International. Retail adept at adapting, New Zealand Retail 2014, Highlights. 2014. Retrieved from http://www.colliers.co.nz.

Coyne, R. The Tuning of Place: Cambridge, MA: MIT Press, 2010.

Crawford, M. "The world in a shopping mall." In Variations on a theme park: The new American city and the end of public space. Edited by M. Sorkin. New York, NY: Hill and Wong, 1992, 3-30.

Davis, M. City of quartz: Excavating the future in Los Angeles. London, England: Verso, 2006.

Dehaene, M. and L. De Cauter. "Heterotopia in a postcivil society." In Heterotopia and the city: Public space in a postcivil society. Edited by M. Dehaene and L. De Cauter. New York, NY: Routledge, 2008a, 3-9.

Dehaene, M. and L. De Cauter. "The space of play: Towards a general theory of heterotopia." In Heterotopia and the city: Public space in a postcivil society. Edited by M. Dehaene and L. De Cauter. New York, NY: Routledge, 2008b, 87-102.

Deleuze, G. and F. Guattari. Anti-Oedipus: Capitalism and schizophrenia. Minneapolis: University of Minnesota Press, 1977.

Dennis. C., A. Newman, R. Michon, J. Brakus and L. T. Wright, L.T. "The mediating effects of perception and emotion: Digital signage in mall atmospherics." Journal of Retailing and Consumer Services 17 (2010): 205-215.

European Union. Glossary: Statistical classification of economic activities in the European Community (NACE). 2008. Retrieved from http://ec.europa.eu/.

Susan Fairgray. Auckland Retail Economic Evidence Base. 2013. Retrieved from www.aucklandcouncil.govt.nz.

Foucault, M. "Of other spaces." In Heterotopia and the city: Public space in a postcivil society. Edited by M. Dehaene and L. De Cauter. New York, NY: Routledge, 2008, 13-29.

Gehl, J. Life between buildings: Using public space. Washington DC: Island Press, 2011.

Gehl, J. Cities for people. Washington, DC: Island Press, 2013.

Goss, J. "The "magic of the mall": An analysis of form, function, and meaning in the contemporary retail built environment." Annals of the Association of American Geographers 83, no. 1 (1993): 18-47. doi:10.1111/j.1467-8306.1993.tb01921.x.

Harvey, D. "The right to the city." New Left Review 53 (2008): 23-40.

Hillier, B. Space is the machine: A configurational theory of architecture. London, England: Space Syntax, 2007.

Hopkins, J. S. "West Edmonton mall: Landscape of myths and elsewhereness." Canadian Geographer 34 (1990): 2-17.

Howard, E. "New shopping centres: Is leisure the answer?" International Journal of Retail \& Distribution Management 35, no. 8 (2007): 661-672.

Humphreys, L. "Mobile social networks and urban public space." New Media \& Society 
12, no. 5 (2010): 763-778.

International Council of Shopping Centres. Canadian mall tenant classification. 2009. Retrieved from http://www.icsc.org/.

International Council of Shopping Centres. Guide for improving tenant mix. 2014. Retrieved from http://www.icsc.org.

Jiven G. and P. J. Larkham. "Sense of place, authenticity and character: A commentary." Journal of Urban Design 8, no. 1 (2003): 67-81. doi:10.1080/13574800320000 64773.

Kim, Y. K., J. Kang and M. Kim. "The relationships among family and social interaction, loneliness, mall shopping motivation, and mall spending of older consumers." Psychology \& Marketing 22, no. 12 (2005): 995-1015. doi:10.10 02/mar.20095.

Kim, Y. K., E. Y. Kim and J. Kang, J. "Teens' mall shopping motivations: Functions of loneliness and media usage." Family and Consumer Sciences Research Journal 32, no. 2 (2003): 140-167. doi:10.1177/1077727X03032002004.

Kitchin, R. and M. Dodge. "Code and the transduction of space." Annals of the Association of American Geographers 95, no. 1 (2005): 162-180. doi:10.1111/ j.1467-8306.2005.00454.x.

Kitchin, R. and M. Dodge. Code/space: Software and everyday life. Cambridge, MA: MIT Press, 2011.

Kitchin, R. and S. Y. Perng. Code and the city. London, England: Routledge, 2016.

Latour, B. Reassembling the social: An introduction to actor-network-theory. London: Oxford University Press, 2005.

Lefebvre, H. Le Droit à la ville. Paris, France: Anthropos, 1968.

Lefebvre, H. The production of space. Oxford, England: Blackwell, 1991.

Lefebvre, $\mathrm{H}$. The urban revolution. Minneapolis: University of Minnesota Press, 1970/2003.

Lin, L. "Indoor city and quasi-public space: A study of the shopping mall system in Hong Kong." China Perspectives 39 (2002): 46-52.

Lynch, K. The image of the city. Cambridge, MA: MIT press, 1960.

Madanipour, A. Whose public space?: International case studies in urban design and development. London, England: Routledge, 2010.

Manfredini, M. and A. Hills, A. "Auckland public space and the evolution of the integrated enclosures of spectacle and consumption." In Intersections. Edited by L. Bravo. Bologna, Italy: City Space Architecture. [In Press].

Manfredini, M. and R. Jenner. "The virtual public thing: De-re-territorialisations of public space through shopping in Auckland's urban space." Interstices: Journal of Architecture and Related Arts 16 (2015): 75-81.

Manfredini, M., R. Jenner and P. Litterick. "Situated and community projects: New technologies: Auckland's public space of spectacle and consumption." Paper Presented at the 8th International Conference and Exhibition of the Association of Architecture Schools of Australasia, Christchurch, New Zealand, 2015.

Manfredini, M., G. Yuen and S. Wu. "Public space and consumption "spatial assemblages": Exploring Macau's places of spectacular otherness." Paper Presented at the $7^{\text {th }}$ International Conference on Planning and Design, Tainan, Taiwan, 2013.

Miles, S. and M. Miles. Consuming cities. New York, NY: Palgrave Macmillan, 2004.

Ministry for the Environment. Urban Design Toolkit. Wellington, New Zealand: Ministry for the Environment, 2009.

Minton, A. Ground control: Fear and happiness in the twenty-first-century city. London, England: Penguin, 2012.

Mitchell, W. J. Me++: The cyborg self and the networked city. Cambridge, MA: MIT 
Press, 2004.

Montgomery, J. "Making a city: Urbanity, vitality and urban design." Journal of Urban Design 3, no. 1 (1998): 93-116. doi:10.1080/13574809808724418.

Mouffe, C. "Deliberative democracy or agonistic pluralism?" Social Research 66, no. 3 (1999): 745-758.

Mouffe, C. "Public spaces and democratic politics." In Highrise-common ground. Art and the Amsterdam Zuidas Area. Edited by J. Boomgaard. Amsterdam, The Netherlands: Valiz, 2008, 135-156.

Nava, M. "Modernity's disavowal: Women, the city and the department store." In Modern times: Reflections on a century of English modernity. Edited by M. Nava \& A. O'Shea. London, England: Routledge, 1996, 38-76.

New Zealand Immigration. Balanced lifestyle. 2015. Retrieved from https://www. newzealandnow.govt.nz.

Nielsen, New Zealand Multi-screen Report, 2015.

Norman, R. and R. Haber. "Eidetic imagery: I. Frequency." Perceptual and Motor Skills 19, no. 1 (1964): 131-138.

Pernecky, T. and T. Jamal. "(Hermeneutic) phenomenology in tourism studies." Annals of Tourism Research 37, no. 4 (2010): 1055-1075.

Popescu, G. "Deterritorialization and reterritorialization." In Encyclopedia of geography. Edited by B. Warf. Thousand Oaks, CA: Sage, 2010, 722-724.

Purcell, M. "Possible worlds: Henri Lefebvre and the right to the city." Journal of Urban Affairs 36, no. 1 (2013): 141-154. doi:10.1111/juaf.12034.

Richards, G. and R. Palmer. Eventful cities: Cultural management and urban revitalisation. Oxford, England: Butterworth-Heinemann, 2010.

Ritzer, G. and N. Jurgenson. Production, consumption, prosumption: The nature of capitalism in the age of the digital "prosumer." Journal of Consumer Culture 10, no. 1 (2010): 13-36. doi:10.1177/1469540509354673.

Ritzer, G., P. Dean and N. Jurgenson. "The coming of age of the prosumer." American Behavioral Scientist 56, no. 4 (2012): 379-398. doi:10.1177/0002764211429368.

Ritzer, G. "Prosumption: Evolution, revolution, or eternal return of the same?" Journal of Consumer Culture November (2013): 1-22. doi:10.1177/146954051 3509641.

Sack, R. Human territoriality: Its theory and history. Cambridge, England: Cambridge University Press, 1986.

Saisana, M. and S. Tarantola. State-of-the-art report on current methodologies and practices for composite indicator development. Ispra, Italy: European Commission, 2002.

Sennett, R. The fall of public man. New York, NY: Random House, 1977.

Sennett, R. The conscience of the eye: The design and social life of cities. New York, NY: Norton, 1992.

Simner, Julia. "Why are there different types of synesthete?" Frontiers in Psychology 4 (2013): 558. doi:10.3389/fpsyg.2013.00558.

Stillerman, J. and R. Salcedo. "Transposing the urban to the mall: Routes, relationships, and resistance in two Santiago, Chile, shopping centers." Journal of Contemporary Ethnography 41, no. 3 (2012): 1-27. doi:10.1177/0891241611434 551.

The world's most "liveable" cities. The Economist. August 18, 2015. Retrieved from www.economist.com.

Turley, L. W. and R. E. Milliman. "Atmospheric effects on shopping behavior. A review of the experimental evidence." Journal of Business Research 49 (2000): 193-211.

Underhill, P. Call of the mall: The geography of shopping. New York, NY: Simon and Schuster, 2005. 
Urban Land Institute. Dollars and cents of shopping centers. Washington, DC: The Land Urban Land Institute, 2008.

Urry, J. The tourist gaze: Leisure and travel in contemporary societies. London, England: Sage, 1990.

Watkins, C. "Representations of space, spatial practices and spaces of representation: An application of Lefebvre's spatial triad." Culture and Organization 11, no. 3 (2005): 209-220. doi:10.1080/14759550500203318.

Whyte, W. H. City: Rediscovering the center. Philadelphia: University of Pennsylvania Press, 2009.

Yamada, T. Index indicator, index display method and recording medium storing index indicator program. Google Patents, 2000.

Zukin, S. Naked city: The death and life of authentic urban. New York, NY: Oxford University Press, 2009.

Zukin, S. and J. S. Maguire. "Consumers and consumption." Annual Review of Sociology 30 (2004): 173-197. doi:10.1146/annurev.soc.30.012703.110553. 